Edubiotik: Jurnal Pendidikan, Biologi dan Terapan

ISSN 2528-679X (print), ISSN 2597-9833 (online)

Volume 4, Nomor 02, Tahun 2019, Hal. 58 - 67

Available online at:

http://ejurnal.budiutomomalang.ac.id/index.php/edubiotik

\title{
Implementasi buku petunjuk praktikum biokimia berbasis inkuiri terbimbing untuk meningkatkan kemampuan kerja ilmiah
}

\author{
Diyah Ayu Widyaningrum, Titik Wijayanti \\ Pendidikan Biologi, IKIP Budi Utomo, Malang, Indonesia \\ E-mail: diyahayuwidyaningrum8905@gmail.com*, kititn71@gmail.com
}

\begin{tabular}{|c|c|}
\hline Informasi Artikel & ABSTRACT \\
\hline $\begin{array}{l}\text { Submit: } \\
13-06-2019 \\
\text { Diterima: } \\
26-08-2019 \\
\text { Dipublikasikan: } \\
01-09-2019\end{array}$ & $\begin{array}{l}\text { Learning material is one of the facilities needed by students to help them find } \\
\text { concepts and answers to their problems. There are various types of learning } \\
\text { materials, one of which is a practical guide. Based on observations on } \\
\text { learning materials and the learning process of Biochemistry courses at IKIP } \\
\text { Budi Utomo Malang shows that there are no practical manuals developed and } \\
\text { students' scientific workability is low. The aim of the research is to improve } \\
\text { students'scientific work abilities through the implementation of guided inquiry- } \\
\text { based biochemistry practicum books. The research method used was } \\
\text { Classroom Action Research. Stages of Classroom Action Research include } \\
\text { planning, implementing, observing, and reflecting. The research instruments } \\
\text { used were interview sheets, observations, and observations of scientific work } \\
\text { capabilities and camera documentation. The results showed that there was an } \\
\text { increase in students' scientific work abilities through the implementation of } \\
\text { guided inquiry-based biochemistry practicum books from cycle I to cycle II in } \\
\text { the amount of } 36.18 \% \text { to } 88.8 \% \text { and N-gain values of } 0.84 \text { (high criteria). } \\
\text { Thus, this research concludes that there is an increase in students' scientific } \\
\text { work abilities through the implementation of guided inquiry-based } \\
\text { biochemistry practicum books. } \\
\text { Key words: Practical instruction, Scientific work ability }\end{array}$ \\
\hline Penerbit & ABSTRAK \\
\hline $\begin{array}{l}\text { Program Studi } \\
\text { Pendidikan Biologi, } \\
\text { Fakultas Pendidikan } \\
\text { Ilmu Eksakta dan } \\
\text { Keolahragaan, IKIP } \\
\text { Budi Utomo, Malang, } \\
\text { Indonesia }\end{array}$ & $\begin{array}{l}\text { Materi pembelajaran adalah salah satu fasilitas yang dibutuhkan peserta didik } \\
\text { untuk membantu mereka menemukan konsep dan jawaban dari } \\
\text { permasalahan mereka. Ada berbagai tipe materi pembelajaran, salah satunya } \\
\text { adalah buku petunjuk praktikum. Berdasarkan observasi pada materi } \\
\text { pembelajaran dan proses pembelajaran matakuliah Biokimia di IKIP Budi } \\
\text { Utomo Malang menunjukkan bahwa tidak ada buku petunjuk praktikum yang } \\
\text { dikembangkan dan kemampuan kerja ilmiah peserta didik rendah. Tujuan } \\
\text { penelitian adalah untuk meningkatkan kemampuan kerja ilmiah mahasiswa } \\
\text { melalui implementasi buku praktikum biokimia berbasis inkuiri terbimbing. } \\
\text { Metode penelitian yang digunakan adalah Penelitian Tindakan Kelas. } \\
\text { Tahapan Penelitian Tindakan Kelas meliputi perencanaan, pelaksanaan, } \\
\text { observasi, dan refleksi. Instrumen penelitian yang digunakan adalah lembar } \\
\text { wawancara, observasi, dan pengamatan kemampuan kerja ilmiah serta } \\
\text { camera dokumentasi. Hasil penelitian menunjukkan bahwa ada peningkatan } \\
\text { kemampuan kerja ilmiah mahasiswa melalui implementasi buku praktikum } \\
\text { biokimia berbasis inkuiri terbimbing dari siklus I ke siklus II yaitu } 36,18 \% \\
\text { menjadi } 88,8 \% \text { dan nilai N-gain sebesar } 0,84 \text { (kriteria tinggi). Dengan } \\
\text { demikian, simpulan penelitian ini adalah ada peningkatan kemampuan kerja } \\
\text { ilmiah mahasiswa melalui implementasi buku praktikum biokimia berbasis } \\
\text { inkuiri terbimbing. } \\
\text { Kata kunci: Kemampuan kerja ilmiah, Petunjuk praktikum }\end{array}$ \\
\hline
\end{tabular}

This Edubiotik : Jurnal Pendidikan, Biologi dan Terapan is licensed under a CC BY-SA (Creative Commons Attribution-ShareAlike 4.0 International License) 


\section{PENDAHULUAN}

Pembelajaran merupakan proses penyusunan informasi dan penataan lingkungan dalam proses penemuan ilmu pengetahuan. Pengertian lingkungan bukan hanya tempat belajar, tetapi juga termasuk didalamnya adalah metode, media, dan instrumen yang dibutuhkan untuk menyampaikan informasi dan membimbing siswa belajar. Informasi yang akan disampaikan dan lingkungan yang akan ditata bersifat fleksibel, tergantung pada tujuan pembelajaran yang ingin dicapai (Sadjati, 2012). Pembelajaran merupakan proses interaksi peserta didik dengan pendidik dan sumber belajar. Oleh karena itu pembelajaran adalah proses pemerolehan informasi yang terjadi akibat adanya interaksi antara pendidik dan peserta didik.

Pendidik memiliki 4 kompetensi dasar yang harus dimiliki antara lain kompetensi pribadi, sosial, pedagogik, dan profesional (Fathorrahman, 2017). Pengembangan kompetensi pedagogik oleh pendidik salah satunya pendidik diharapkan mampu mengembangkan bahan ajar dan mengembangkan kegiatan pembelajaran yang interaktif. Bahan ajar adalah bahan atau materi yang disusun secara sistematis, bersifat unik dan spesifik, yang digunakan pendidik dan peserta didik dalam proses pembelajaran. Macam-macam bahan ajar antara lain cetak dan noncetak. Bahan ajar cetak misalnya modul, handout, dan lembar kerja. Bahan ajar non cetak antara lain realia, bahan ajar yang dikembangkan dari barang sederhana, bahan ajar diam dan display, video, audio, dan overhead tranparencies/OHT(Sadjati, 2012). Buku petunjuk praktikum merupakan salah satu contoh bahan ajar cetak.

Petunjuk praktikum merupakan salah satu media pembelajaran yang berisi tentang pelaksanaan kegiatan-kegiatan praktikum serta prosedur praktikum sehingga dapat membantu pendidik dan peserta didik dalam kelancaran proses kegiatan praktikum. Proses kegiatan praktikum dapat ditunjang dengan model-model pembelajaran yang interaktif sehingga dapat meningkatkan kemampuan kerja ilmiah mahasiswa (Nengsi, 2016). Berdasarkan hasil observasi kegiatan praktikum Biokimia di IKIP Budi Utomo Malang, mahasiswa belum secara sistematis melaksanakan kegiatan praktikum, terbukti dengan kegiatan praktikum dengan mengacu pada selembar kertas sebagai panduan kegiatan. Kegiatan praktikum antara lain melihat demonstrasi dari dosen, melakukan kegiatan praktikum sesuai demonstrasi dari dosen, memperoleh data dan membuat laporan praktikum. Mahasiswa seharusnya dilatih kemampuan bekerja ilmiahnya melalui kegiatan praktikum.

Kerja ilmiah adalah keterampilan dasar yang harus dikembangkan dan dilatih, sebelum menggunakan metode ilmiah. Aspek kerja ilmiah antara lain mahasiswa mampu merencanakan penelitian ilmiah, melaksanakan penelitian ilmiah, mengkomunikasikan hasil penelitian ilmiah dan bersikap ilmiah (Rustaman \& Rustaman, 2010). Merencanakan penelitian ilmiah meliputi membuat perencanaan penelitian sederhana meliputi menetapkan dan merumuskan tujuan penelitian, langkah kerja, hipotesis, variabel dan instrumen yang tepat untuk tujuan penelitian. Melaksanakan penelitian ilmiah meliputi mahasiswa mampu melaksanakan langkahlangkah kerja ilmiah yang terorganisir dan menarik kesimpulan terhadap hasil penemuannya. Mengkomunikasikan hasil penelitian ilmiah meliputi mahasiswa mampu menyajikan hasil penelitian dan kajiannya dengan berbagai cara kepada berbagai kelompok sasaran. Bersikap ilmiah meliputi mahasiswa mengembangkan 
sikap antara lain keingintahuan, berani dan santun, kepedulian lingkungan, berpendapat secara ilmiah dan kritis, bekerjasama, jujur dan tekun (Simatupang, 2014).

Kegiatan praktikum dapat menggunakan buku petunjuk praktikum berbasis model pembelajaran salah satunya inkuiri terbimbing. Model pembelajaran inkuiri terbimbing digunakan bagi siswa yang belum berpengalaman belajar dengan menggunakan model inkuiri. Pada tahap permulaan diberikan bimbingan yang nantinya perlahan-lahan bimbingan itu dikurangi. Sebagian besar perencanaan pembelajaran dan lembar penyusunan laporan dilakukan oleh pendidik dalam inkuiri terbimbing (Udiani, Marhaeni, \& Arnyana, 2017). Hasil penelitian terdahulu berkaitan dengan buku petunjuk praktikum dan model inkuiri terbimbing antara lain Prayitno (2017) menunjukkan hasil bahwa pengembangan petunjuk praktikum mikrobiologi memenuhi kriteria valid. Alexander, Rahayu, \& Kurniawan (2018) menunjukkan hasil bahwa pengembangan penuntun praktikum fotosintesis berbasis audiovisual camtacia studio memenuhi kriteria sangat valid. Ariningsih \& Nawawi (2014)pengembangan panduan praktikum kimia berbasis inkuiri terstruktur di kelas XII SMAN 1 indralaya utara memenuhi kategori baik dan sangat praktis. Nengsi (2016)mengenai pengembangan penuntun praktikum biologi umum berbasis inkuiri terbimbing untuk mahasiswa biologi STKIP Payakumbuh memenuhi kriteria valid, praktis dan efektif. Pengembangan buku petunjuk praktikum Biokimia berbasis inkuiri terbimbing terhadap keterampilan kerja ilmiah belum pernah diteliti sebelumnya. Berdasarkan paparan diatas, tujuan penelitian yang ingin dicapai adalah meningkatkan kemampuan kerja ilmiah mahasiswa IKIP Budi Utomo melalui implementasi buku praktikum biokimia berbasis inkuiri terbimbing.

\section{METODE PENELITIAN}

Penelitian ini merupakan Penelitian Tindakan Kelas (PTK) yang dilaksanakan selama dua siklus. Setiap siklus terdiri dari tiga pertemuan dengan beberapa tahap diantaranya; perencanaan tindakan, pelaksanaan tindakan, observasi tindakan dan refleksi. Penelitian dilaksanakan di Program Studi Pendidikan Biologi IKIP Budi Utomo Malang pada tahun ajaran 2018/2019. Populasi penelitian adalah semua mahasiswa Program Studi Pendidikan Biologi IKIP Budi Utomo Malang. Sampel penilitian yaitu mahasiswa Program Studi Pendidikan Biologi yang sedang menempuh matakuliah Biokimia.

Data dan sumber data yang digunakan dalam penelitian ini adalah seluruh hasil pengamatan terhadap keadaan pembelajaran yang sebenarnya dan mengandung informasi yang relevan dengan kegiatan penelitian. Data penelitian dikumpulkan dari berbagai sumber, antara lain melalui wawancara dengan dosen pengampu matakuliah Biokimia dan proses kegiatan praktikum matakuliah Biokimia serta melalui dokumen yang berisi Silabus, Rencana Pelaksanaan Pembelajaran (RPP), dan foto selama pembelajaran.

Teknik pengumpulan data dalam penelitian ini menggunakan lembar pengamatan kemampuan kerja ilmiah mahasiswa. Sedangkan, teknik pengumpulan data pendukung menggunakan lembar wawancara dan foto dokumentasi pembelajaran. Instrumen wawancara berupa lembar wawancara mengenai 
kemampuan kerja ilmiah dengan jumlah item pertanyaan sebanyak 10 soal. Wawancara digunakan untuk mengetahui pernah atau tidaknya dilakukan penilaian terhadap kemampuan kerja ilmiah mahasiswa. Wawancara dilakukan terhadap dosen pengampu dan 20 mahasiswa yang pernah mengikuti matakuliah Biokimia. Hasil wawancara dianalisis secara deskriptif. Foto dokumentasi dilakukan terhadap aktivitas kerja ilmiah mahasiswa selama pembelajaran praktikum. Instrumen dokumentasi berupa kamera. Hasil dokumentasi dianalisis secara deskriptif. Teknik analisis data dalam penelitian ini menggunakan analisis kualitatif dan kuantitatif. Analisis data secara kualitatif yaitu dengan mendeskripsikan hasil pengamatan pembelajaran praktikum dengan mengunakan buku petunjuk praktikum biokimia berbasis inkuiri terbimbing. Sedangkan analisis data secara kuantitatif yaitu dengan menghitung rata-rata hasil kemampuan kerja ilmiah pada akhir tiap siklus dan nilai $N$ gain.

\section{HASIL PENELITIAN DAN PEMBAHASAN}

Tahapan kegiatan pada penelitian tindakan kelas meliputi perencanaan, pelaksanaan, observasi dan refleksi. Selama proses kegiatan melibatkan satu guru model, empat observer, dan 40 mahasiswa. Penelitian tindakan kelas dilaksanakan sebanyak 2 siklus, yang dilaksanakan mulai tanggal 4 Juli 2018 sampai dengan 8 Agustus 2018.Tindakan yang diberikan berupa pemberian buku petunjuk praktikum yang berisi langkah-langkah pembelajaran dengan model inkuiri terbimbing. Inkuiri terbimbing dilaksanakan dengan tahapan sebagai berikut. (1) Identifikasi masalah. (2) Rumusan permasalahan. (3) Perumusan hipotesis. (4) pengumpulan data. (5) Interpretasi data. (6) Kesimpulan. (7) Review. Seluruh mahasiswa dibagi menjadi 8 kelompok sehingga masing-masing kelompok beranggotakan 5 orang yang memiliki kemampuan akademis yang berbeda.

Data aktivitas dosen diperoleh dengan observasi selama pembelajaran berlangsung. Berdasarkan Tabel 1 skor perolehan aktivitas dosen pada siklus 1 yakni 9,75 dari skor seharusnya yakni 28 . Hal tersebut menunjukkan aktivitas dosen dalam pembelajaran menggunakan buku petunjuk praktikum berbasis inkuiri terbimbing belum maksimal. Skor terendah diperoleh pada item 1 yaitu membimbing mahasiswa mengidentifikasi permasalahan. Dosen masih kesulitan dalam membimbing mahasiswa mengidentifikasi permasalahan dari artikel yang terdapat pada buku petunjuk praktikum.

Tabel 1. Aktivitas Dosen Siklus 1

\begin{tabular}{llcc}
\hline No & \multicolumn{1}{c}{ Indikator } & Jumlah Item & Skor Perolehan \\
\hline 1 & Membimbing mahasiswa mengidentifikasi & 1 & 1 \\
& permasalahan & 1 & 1,25 \\
2 & Membimbing mahasiswa merumuskan permasalahan & 1 & 1,25 \\
3 & Membimbing mahasiswa merumuskan hipotesis & 1 & 1,5 \\
4 & Membimbing siswa mengumpulkan data & 2 & 1,75 \\
5 & Membimbing siswa menginterpretasi data & 1 & 1,5 \\
6 & Membimbing siswa membuat kesimpulan & 1 & 1,5 \\
7 & Membimbing siswa melakukan review & $\mathbf{8}$ & $\mathbf{9 , 7 5}$ \\
\hline
\end{tabular}


Tabel 2 menunjukkan rerata kemampuan kerja ilmiah mahasiswa pada siklus 1 sebesar 36,18. Hal tersebut menunjukkan bahwa kemampuan kerja ilmiah mahasiswa pada siklus 1 masih sangat rendah. Pada tahap refleksi, observer mengemukakan bahwa dosen dan mahasiswa pada siklus 1 masih beradaptasi dengan bahan ajar dan model pembelajaran inkuiri terbimbing. Dosen sebaiknya menjelaskan model pembelajaran yang akan digunakan pada saat pembelajaran serta membimbing mahasiswa menggunakan pertanyaan-pertanyaan yang mengarah ke permasalahan yang akan diidentifikasi oleh mahasiswa, sehingga mahasiswa tidak bingung. Apabila belum berhasil, dosen dapat memberikan contoh 1 permasalahan dari artikel yang terdapat pada buku petunjuk praktikum. Kemampuan kerja ilmiah mahasiswa yang rendah pada siklus 1 perlu adanya perbaikan dan peningkatan pada siklus 2 .

Tabel 2. Kemampuan Kerja IImiah Mahasiswa Siklus 1 dan 2

\begin{tabular}{|c|c|c|}
\hline No & Siklus 1 & Siklus 2 \\
\hline 1 & 44 & 81 \\
\hline 2 & 50 & 94 \\
\hline 3 & 44 & 94 \\
\hline 4 & 31 & 88 \\
\hline 5 & 50 & 94 \\
\hline 6 & 25 & 94 \\
\hline 7 & 44 & 88 \\
\hline 8 & 25 & 88 \\
\hline 9 & 19 & 81 \\
\hline 10 & 31 & 94 \\
\hline 11 & 38 & 94 \\
\hline 12 & 38 & 81 \\
\hline 13 & 56 & 88 \\
\hline 14 & 25 & 81 \\
\hline 15 & 38 & 94 \\
\hline 16 & 25 & 81 \\
\hline 17 & 25 & 88 \\
\hline 18 & 38 & 88 \\
\hline 19 & 44 & 88 \\
\hline 20 & 50 & 94 \\
\hline 21 & 25 & 88 \\
\hline 22 & 25 & 94 \\
\hline 23 & 50 & 94 \\
\hline 24 & 56 & 94 \\
\hline 25 & 31 & 94 \\
\hline 26 & 38 & 88 \\
\hline 27 & 38 & 88 \\
\hline 28 & 44 & 81 \\
\hline 29 & 50 & 94 \\
\hline 30 & 25 & 81 \\
\hline 31 & 25 & 81 \\
\hline
\end{tabular}




\begin{tabular}{ccc}
\hline No & Siklus 1 & Siklus 2 \\
\hline 32 & 25 & 81 \\
\hline 33 & 50 & 94 \\
\hline 34 & 50 & 94 \\
\hline 35 & 31 & 88 \\
\hline 36 & 19 & 81 \\
\hline 37 & 31 & 94 \\
\hline 38 & 38 & 88 \\
\hline 39 & 25 & 94 \\
\hline 40 & 31 & 88 \\
\hline Jumlah & $\mathbf{1 4 4 7}$ & $\mathbf{3 5 5 2}$ \\
\hline Rerata & $\mathbf{3 6 , 1 8}$ & $\mathbf{8 8 , 8}$ \\
\hline
\end{tabular}

Tabel 3 menunjukkan skor perolehan aktivitas dosen pada siklus 2 yakni 27,25 dari skor seharusnya yakni 28 . Hal tersebut menunjukukan aktivitas dosen dalam pembelajaran menggunakan buku petunjuk praktikum berbasis Inkuiri terbimbing telah maksimal. Skor maksimal diperoleh pada item 3,4,6, dan 7. Item 3 adalah membimbing mahasiswa merumuskan hipotesis. Item 4 adalah membimbing siswa mengumpulkan data. Item 6 adalah membimbing siswa membuat kesimpulan, dan item 7 membimbing siswa melakukan review. Pada Tabel 2 menunjukkan kemampuan kerja ilmiah mahasiswa menunjukkan rerata 88,8. Mahasiswa telah menerapkan kemampuan kerja ilmiah dengan sangat baik. Hampir seluruh aspek/indikator kemampuan kerja ilmiah mahasiswa maksimal.

Tabel 3. Aktivitas Dosen Siklus 2

\begin{tabular}{clcc}
\hline No & Indikator & Jumlah Item & Skor Perolehan \\
\hline 1 & Membimbing mahasiswa mengidentifikasi permasalahan & 1 & 3,75 \\
2 & Membimbing mahasiswa merumuskan permasalahan & 1 & 3,75 \\
3 & Membimbing mahasiswa merumuskan hipotesis & 1 & 4 \\
4 & Membimbing siswa mengumpulkan data & 1 & 4 \\
5 & Membimbing siswa menginterpretasi data & 2 & 3,75 \\
6 & Membimbing siswa membuat kesimpulan & 1 & 4 \\
7 & Membimbing siswa melakukan review & 1 & 4 \\
\hline & Total & $\mathbf{8}$ & $\mathbf{2 7 , 2 5}$ \\
\hline
\end{tabular}

Tabel 4. $\mathbf{N}$-Gain Kemampuan kerja IImiah Mahasiswa

\begin{tabular}{ccc}
\hline Siklus 1 (\%) & Siklus 2 (\%) & $\mathbf{N}$-Gain \\
\hline 36,17 & 88,80 & 0,84 \\
\hline
\end{tabular}

Peningkatan kemampuan kerja ilmiah mahasiswa dari siklus 1 ke siklus 2 sebesar 52,62\%. N-Gain kemampuan kerja ilmiah mahasiswa sebesar 0,84 menunjukkan kriteria tinggi. Pembelajaran untuk meningkatkan kinerja ilmiah merupakan pembelajaran dimana peserta didik dilibatkan pada permasalahan yang terbuka, bersifatterpusat pada siswadan melibatkan hands-on (Colburn, 1997). Melalui eksperimen mahasiswa mampu mengembangkan dan mengevaluasi metode ilmiah diantaranya mengemukakan argumentasi. Ciri eksperimen inkuiri yaitu mengembangkan pembelajaran yang berpusat pada peserta didik dengan tugas yang bercirikan masalah inkuiri (Khanafiyah, 2010). 
Buku petunjuk praktikum berbasis inkuiri terbimbing dapat meningkatkan kerja ilmiah mahasiswa. Partisipasi mahasiswa dalam kegiatan penyelidikan melalui praktikum mendorong mahasiswa untuk mengajukan pertanyaan, merumuskan hipotesis, melakukan percobaan, menggunakan alat untuk mengumpulkan data, menganalisis data, menyimpulkan dan berargumen merupakan serangkaian kegiatan yang dapat mengembangkan kemampuan kerja ilmiah mahasiswa dan membuat mahasiswa belajar secara aktif dalam menemukan konsep.

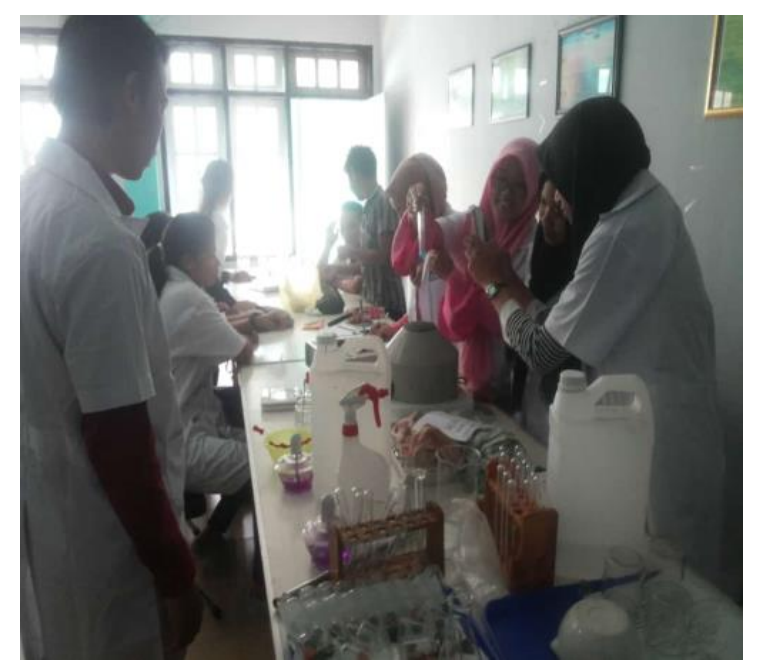

Gambar 1. Kegiatan Praktikum Mahasiswa

(Sumber: Dokumentasi Pribadi, 2018)

Gambar 1 menunjukkan kegiatan praktikum yang mencerminkan inkuiri terbimbing dan kinerja ilmiah yaitu pada tahapan melakukan percobaan dan menggunakan alat-alat laboratorium untuk mengumpulkan data. Data yang diperoleh selanjutnya dilakukan analisis dan disimpulkan. Langkah terakhir adalah mempresentasikan hasil praktikum.

Kerja ilmiah yang dilakukan mahasiswa selama kegiatan laboratorium memberi peningkatan pada kemampuan menyusun laporan praktikum. Laporan praktikum yang disusun oleh mahasiswa telah mengikuti metode ilmiah meliputi perumusan permasalahan, menyusun hipotesis, menentukan alat dan bahan, menyusun prosedur kerja, mengumpulkan data, menganalisis data, melakukan pembahasan dan menarik kesimpulan. Buku petunjuk praktikum berbasis inkuiri terbimbing dapat meningkatkan kemampuan kerja ilmiah mahasiswa karena langkah-langkah inkuiri terbimbing mencerminkan metode ilmiah. Hal ini sejalan dengan penelitian yang dilakukan oleh Khasanah, Sarwanto, \& Radiyono (2016) menunjukkan bahwa model inkuiri terbimbing dapat meningkatkan sikap ilmiah dan kemampuan kognitif siswa. Hasil observasi sikap ilmiah siswa meningkat dari siklus 1 sampai siklus 2 dan mencapai target ketercapaian pada siklus 2 . Hal ini sesuai dengan hasil penelitian terdahulu bahwa model inkuiri terbimbing dan penuntun praktikum dapat meningkatkan hasil belajar dan keterampilan proses sains siswa pada materi fluida statis (Zani, Adlim, \& Safitri 2017). Aktivitas mahasiswa dapat ditingkatkan dengan kegiatan praktikum dengan menggunakan penuntun praktikum (Nengsi 2016). 
Pengembangan buku penuntun praktikum yang valid dan praktis mampu mengarahkan kegiatan praktikum dengan tepat (Putri, Hasnunidah, \& Yolida, 2018).

Peneliti tidak hanya mengembangkan buku petunjuk praktikum Biokimia dengan berbasis pada suatu model pembelajaran yaitu inkuiri terbimbing, namun peneliti juga melihat kebermanfaatan produk yang dikembangkan yaitu peningkatan pada kemampuan kerja ilmiah mahasiswa. Hal ini berarti bahwa mahasiswa telah aktif dalam melakukan kegiatan praktikum dengan menggunakan penuntun praktikum berbasis inkuiri terbimbing. Keaktifan mahasiswa selama proses praktikum dengan menggunakan penuntun praktikum berbasis inkuiri terbimbing menunjukkan pelaksanaan kinerja ilmiah. Hal ini sesuai dengan pernyataan Syamsu (2017) bahwa mahasiswa akan mendapatkan gambaran tentang tujuan, manfaat dan proses kegiatan praktikum yang akan dilakukan dengan adanya buku petunjuk praktikum. Selain itu, penuntun praktikum berbasis inkuiri terbimbing dapat melatih keterampilan ilmiah mahasiswa seperti seorang scientis dalam melakukan praktikum. Mahasiswa lebih mudah memahami konsep rumit dan abstrak jika disertai dengan contoh konkret atau melalui benda nyata, sehingga mahasiswa belajar secara aktif dan kreatif dalam mengembangkan kemampuan mencoba yang mereka miliki.Inkuiri terbimbing penting diterapkan dalam proses belajar mengajar agar mahasiswa dapat berlatih untuk selalu bertanya, berpikir kritis, menumbuh kembangkan keterampilan fisik dan mental.

Indikator terakhir dari kerja ilmiah yaitu sikap ilmiah. Sikap ilmiah peserta didik yang dibelajarkan dengan model pembelajaran inkuiri terbimbing lebih baik daripada sikap ilmiah peserta didik yang dibelajarkan dengan model pembelajaran konvensional. Hal ini dikarenakan dalam pembelajaran menggunakan model inkuiri terbimbing yang ditekankan adalah prosesnya, pembelajaran yang berpusat pada peserta didik, yang mendorong peserta didik untuk lebih aktif dan dapat menemukan jawaban sendiri atas permasalahan yang dihadapi baik melalui percobaan atau pencatatan informasi. Peserta didik akan mendapat bimbingan sehingga memperoleh pengetahuan sendiri melalui pengalaman secara langsung dan dapat mendorong sikap ilmiah peserta didik pada diri peserta didik seperti sikap hasrat ingin tahu, kritis, terbuka dan kerja sama (Dewi, Dantes, \& Sadia, 2013).

\section{SIMPULAN DAN SARAN}

Berdasarkan hasil penelitian dan pembahasan, maka simpulan penelitian iniadalah ada peningkatkan kemampuan kerja ilmiah mahasiswa melalui implementasi buku praktikum biokimia berbasis inkuiri terbimbingdengan peningkatan dari siklus 1 ke siklus 2 sebesar $52,62 \%$ dan nilai $\mathrm{N}$-Gain sebesar 0,84 (kategori tinggi). Saran yang dapat diberikan berdasarkan hasil penelitian adalah perlu penelitian lebih lanjut dengan menggunakan model lain danmenggunakan lebih dari satu kelas sebagai treatment. Perlu penelitian panjang dengan sampel beberapa Perguruan Tinggi sehingga produk buku petunjuk praktikum biokimia berbasis inkuiri terbimbing dapat disebarluaskan. 


\section{UCAPAN TERIMA KASIH}

Ucapan terimakasih kami tujukan kepada Ristekdikti yang telah memberikan dana penelitian dan semua pihak yang terlibat pada pelaksanaan penelitian sehingga penelitian kami dapat berjalan dengan baik dan lancar.

\section{RUJUKAN}

Alexander, A., Rahayu, H. M., \& Kurniawan, A. D. (2018). Pengembangan Penuntun Praktikum Fotosintesis Berbasis Audio Visual Menggunakan Program Camtacia Studio di SMAN 1 Hulu Gurung. Jurnal Pendidikan Sains Indonesia, 6(2), 7582. https://doi.org/10.24815/jpsi.v6i2.12075

Ariningsih, I., \& Nawawi, E., Hartono. (2014). Inkuiri Terstruktur Di Kelas XII SMAN 1 Indralaya Utara. Jurnal Penelitian Pendidikan Kimia, 1(2), 147-155. Retrieved from https://ejournal.unsri.ac.id/index.php/jurpenkim/article/download/1893/789

Colburn, A. (1997). How To Make Lab Activities More Open Ended. California Science Teachers Association. Retrieved from https://www.cirm.ca.gov/

Dewi, N. L., Dantes, N., \& Sadia, I. W. (2013). Pengaruh Model Pembelajaran Inkuiri Terbimbing Terhadap Sikap IImiah Dan Hasil Belajar IPA. Jurnal Pendidikan Dasar, 3(1). Retrieved from http://oldpasca.undiksha.ac.id/e-journal/index.php/ jurnal_pendas/article/view/512/304

Fathorrahman. (2017). Kompetensi Pedagogik, Profesional, Kepribadian Dan Kompetensi Sosialdosen. Jurnal Akademika, 15(1), 1-6. Retrieved from http://jurnal.stieimalang.ac.id/index.php/JAK/article/download/67/33.\%20(Diakse s\%203\%20Januari\%202019)

Khanafiyah, S. (2010). Pengembangan Keterampilan Kerja IImiah Mahasiswa Calon Guru Fisika Melalui Eksperimen Gelombang Open-Inquiry. Jurnal Pendidikan Fizika Indonesia, 6(2), 115-122. Retrieved from https://journal.unnes.ac.id/ nju/index.php/JPFI/article/download/1123/1041

Khasanah, N. I., Sarwanto, \& Radiyono, Y. (2016). Penerapan Model Pembelajaran Inkuiri Terbimbing Untuk Meningkatkan Sikap IImiah Dan Kemampuan Kognitif Siswa Pada Pembelajaran Fisika Kelas X MIPA 6 di SMA Negeri 1 Karanganyar. In Seminar Nasional Pendidikan Sains (pp. 309-316). Retrieved from http://jurnal.fkip.uns.ac.id/index.php/snps/article/view/9853/7283

Nengsi, S. (2016). Jurnal Ipteks Terapan. Pengembangan Penuntun Praktikum Biologi Umum Berbasis Inkuiri Terbimbing Mahasiswa Biologi Stkip Payakumbuh. Jurnal Ipteks Terapan, 47-55. Retrieved from https://www.researchgate.net

Prayitno, T. A. (2017). Pengembangan Petunjuk Praktikum Mikrobiologi Program Studi Pendidikan Biologi. Jurnal Biota, 3(1), 31. https://doi.org/10.19109/Biota.v3i1.1041

Putri, Z. M., Hasnunidah, N., \& Yolida, B. (2018). Pengembangan Buku Penuntun Praktikum Struktur dan Fungsi Tumbuhan dengan Model Argument-Driven Inquiry (ADI). Bioterdidik. Retrieved from http://jurnal.fkip.unila.ac.id/index.php /JBT/article/view/15195

Rustaman, N. y, \& Rustaman, A. (2010). Kemampuan Kerja Ilmiah Dalam Sains (pp. 1-16). Retrieved from http://file.upi.edu/browse.php?dir=Direktori 
Sadjati, I. M. (2012). Hakikat Bahan Ajar. Pengembangan Bahan Ajar, 1-62. Retrieved from http://repository.ut.ac.id/4157/1/IDIK4009-M1.pdf

Simatupang, H. (2014). Peningkatan kerja ilmiah dalam praktikum biologi dengan keterampilan proses mahasiswa semester $\mathrm{i}$ jurusan biologi universitas negeri medan. In Proseding Seminar Nasional dan Pembelajarannya (pp. 480-487). Retrieved from http://digilib.unimed.ac.id/

Syamsu, F. D. (2017). Pengembangan Penuntun Praktikum IPA Berbasis Inkuiri Terbimbing Untuk Siswa SMP Kelas VII. Bionatural, 4(2), 13-27. Retrieved from https://ejournal.stkipbbm.ac.id/index.php/bio/article/download/190/177

Udiani, N. K., Marhaeni, A. A. I. N., \& Arnyana, I. B. P. (2017). Pengaruh Model Pembelajaran Inkuiri Terbimbing Keterampilan Proses Sains Siswa Kelas Iv. EJournal Program Pascasarjana Universitas Pendidikan Ganesha, 7(1), 4-11. Retrieved from http://oldpasca.undiksha.ac.id/e-journal/index.php/jurnal_pendas /article/view/2242

Zani, R., Adlim, A., \& Safitri, R. (2017). Penerapan Model Pembelajaran Inkuiri Terbimbing pada Materi Fluida Statis Untuk Meningkatkan Hasil Belajar dan Keterampilan Proses Sains Siswa. In Prosiding Seminar Nasional Pascasarjana (SNP) Unsyiah (pp. 173-180). https://doi.org/10.24815/jipi.v2i2.11622 